\title{
Urinary Prognostic Biomarkers in Patients With Focal Segmental Glomerulosclerosis
}

\author{
Shiva Kalantari ${ }^{1}$; Mohsen Nafar ${ }^{2,3,4^{*}}$; Shiva Samavat ${ }^{2,3,4}$; Mostafa Rezaei-Tavirani ${ }^{5}$; Dorothea \\ Rutishauser $^{6,7}$; Roman Zubarev ${ }^{6,7}$ \\ ${ }^{1}$ Department of Basic Sciences, Faculty of Paramedical Sciences, Shahid Beheshti University of Medical Sciences, Tehran, IR Iran \\ ${ }_{3}^{2}$ Department of Nephrology, Shahid Labbafinejad Medical Center, Shahid Beheshti University of Medical Sciences, Tehran, IR Iran \\ ${ }_{3}^{3}$ Urology and Nephrology Research Center, Shahid Beheshti University of Medical Sciences, Tehran, IR Iran \\ ${ }^{4}$ Chronic Kidney Disease Research Center, Shahid Beheshti University of Medical Sciences, Tehran, IR Iran \\ ${ }_{5}^{5}$ Proteomics Research Center, Shahid Beheshti University of Medical Sciences, Tehran, IR Iran \\ ${ }_{6}$ Proteomics Research Center, Shahid Beheshti University of Medical Sciences, Tehran, IR Iran
${ }_{7}$ Department of Medical Biochemistry and Biophysics, Karolinska Institute, Stockholm, Sweden \\ ${ }_{7}^{7}$ Department of Medical Biochenab, Stockholm, Sweden \\ * Corresponding author: Mohsen Nafar, Department of Nephrology, Shahid Labbafinejad Medical Center, Shahid Beheshti University of Medical Sciences, Tehran, IR Iran. Tel/Fax: \\ +98-2122580333, E-mail: nafar@sbmu.ac.ir
}

Received: December 11, 2013; Revised: December 29, 2013; Accepted: January 2, 2014

\begin{abstract}
Background: Focal segmental glomerulosclerosis (FSGS) is a type of nephrotic syndrome which is diagnosed by renal biopsy. Degree of the proteinuria, renal dysfunction, histologic findings and the response to therapy are some factors used for evaluating the prognosis of FSGS.

Objectives: In the present study, we attempted to discover some protein candidates for disease prognosis related to glomerular filtration rate(renal dysfunction).

Patients and Methods: Urine samples were collected from ten patients.Urine proteome was extracted and trypsinated. Digested peptides were separated and identified by nano-flow LC-MS/MS. Protein content were determined using label-free quantification method. Protein profiles were analyzed using supervised multivariate statistical method.

Results: Output of a predictive model was 54 significant proteins of which ribonuclease 2 and haptoglobin had the greatest fold change in terms of overrepresentation and underrepresentation in patients with the best and worse prognosis, respectively. Complement and coagulation cascades were the only significant pathways which were impaired in FSGS.

Conclusions:Urinary biomarkers can potentially be used as non-invasive prognostic markers. However these candidate biomarkers need further validation by an alternative method and in a larger cohort.
\end{abstract}

Keywords:Complement Activation; Ribonuclease, Haptoglobins; Renal Dysfunction

\section{Background}

Focal segmental glomerulosclerosis (FSGS) is a type of nephrotic syndrome which is diagnosed using renal biopsy and may be found as either primary or secondary conditions. Primary FSGS occurs without an identifiable cause and the secondary type occurs in response to previous glomerular injury, glomerular hypertension, or hypertrophy (1). While the clinical presentation of FSGS is often heterogeneous, a characteristic feature of the disease is proteinuria due to loss of filtration barrier of glomeruli (2). Histological characteristics of FSGS also include scattered sclerosis of glomeruli in which only a segment of the capillary is affected (3). It is the most common cause of acquired chronic renal insufficiency in children and frequently leads to progression to the end-stage kidney disease (ESKD) (4). Factors that appear to mainly affect the prognosis include the degree of proteinuria and renal dysfunction, histologic findings, and the response to therapy. In the present study we focused on the discovery of urinary proteins responsible for developing more severe renal dysfunction as a prognostic factor using proteomics tools.

\section{Objectives}

In the present study, we attempted to discover urinary excreted proteins which can be used for the differentiation of patients with good and bad prognosis. These noninvasive biomarker candidates would be useful in the follow-up and detection of disease progression without using biopsy.

\section{Patients and Methods}

Second morning urine samples were collected from 11 patients with biopsy proven FSGS (male $=7$, female $=4$, mean age $=36.36$ ), at Labbafinejad Hospital during 2011 .

Implication for health policy/practice/research/medical education:

The prognostic biomarkers discovered in the urine would be useful in non-invasive monitoring and diagnosis of focal segmental glomerulosclerosis (FSGS) and can be used as a surrogate for biopsy in the diagnosis and follow up of the disease progression.

Copyright (c) 2014, Nephrology and Urology Research Center; Published by Kowsar Corp. This is an open-access article distributed under the terms of the Creative Commons Attribution License, which permits unrestricted use, distribution, and reproduction in any medium, provided the original work is properly cited. 
For each patient eGFR was calculated by CKD-EPI equation at presentation. In order to study differential proteins among good and bad prognosis patients, we categorized all patients based on eGFR. Since more severe renal dysfunction at presentation is generally associated with poor renal survival (5), five patients considered as mild disease state $\left(e G F R>60 \mathrm{cc} / \mathrm{min} / 1.73 \mathrm{~m}^{2}\right.$ ) and five patients with advanced disease state and worse prognosis (eGFR $<60 \mathrm{cc}$ ) $\min / 1.73 \mathrm{~m}^{2}$ ) were enrolled. Urine samples were concentrated and desalted with ultrafiltration (Millipore, Billerica, MA, USA with a $3 \mathrm{kDa}$ cut off) and then were treated with acetone (up to $80 \% \mathrm{v} / \mathrm{v}$ ), dried and re-suspended in $0.1 \mathrm{M}$ ammonium acetate ( $\mathrm{pH}$ 5). Protein concentration was then determined using the BCA (bicinchoninicacid) protein assay (Pierce, Thermo Scientific, USA) and proteins were further digested by trypsin. Digested peptides were suspended in an appropriate buffer and injected to a liquid chromatography tandem mass spectrometry (nLCMS/MS) coupled online to a Q Exactive mass spectrometer (both-Thermo Scientific, Bremen, Germany). For details of the sample preparation protocol, MS analysis and labelfree quantification procedure see the article of Kalantari et al. (6). Protein profiles then were analyzed using supervised multivariate statistical analysis. Patients were categorized based on GFR (renal dysfunction). A predictive model was then constructed and validated by 7 fold crossvalidation and significant proteins were determined. Gene-set enrichment and pathway analysis on significant proteins were performed using "DAVID” software.

\section{Results}

Urinary protein profiles of FSGS patients using 110 protein entries were quantified as described by Kalantari et al. (7). Differential proteins between the two groups with different prognosis features (eGFR $<60$ and $>60 \mathrm{cc} / \mathrm{min} / 1.73$ $\mathrm{m}^{2}$ ) were obtained using orthogonal projection to latent structures discriminant analysis (OPLS-DA) (8). A predictive model was constructed by this method (Q2 $=0.861$ and R2 $=0.619$ ) which had 100\% accuracy (Figure 1). Fifty four significant biomarkers were obtained from the predictive model of which top twelve (six most positively and six most negatively correlating with GFR) are described in Table 1 as putative FSGS progression biomarkers.

\section{Discussion}

Prognosis is important to patients, clinicians, public health, and health policy makers and glomerular filtration rate (GFR) is one of the effective prognostic factors for patients with declining renal function $(9,10)$ and glomerular diseases. Urinary biomarkers derived from a predictive model which reflect the prognosis of glomerular diseases (based on GFR in the current study) could be considered as useful noninvasive markers for rapid, reliable and accurate diagnosis and monitoring the progression of the disease in comparison with current traditional invasive approaches, however the causes of

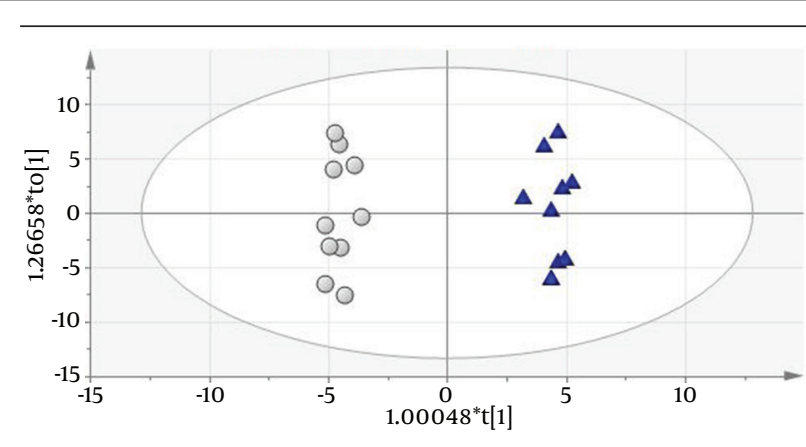

Figure 1. Predictive Model Constructed Using "SIMCA". Open Circles Represent Patients With Better Prognosis and Dark Triangles Represent Patients With Worse Prognosis

up/down regulation of these candidates is not clear and need further experiments. Some of the most significant biomarker candidates are presented here:

RNAS2 had the greatest-fold change (7.32) as the overrepresented biomarker in patients with worse prognosis $\left(\right.$ eGFR $\left.<60 \mathrm{cc} / \mathrm{min} / 1.73 \mathrm{~m}^{2}\right)$. A strong correlation between serum RNase levels and renal insufficiency was previously reported by Humphrey et al. (11). RNAS2 is a $3 \mathrm{kDa}$ protein which is found in body fluids (including urine) (12) and some tissues. The pathologic reason of its urinary elevation in glomerulosclerosis is not clear; however, to the best of our knowledge, it is reported here for the first time as a prognostic candidate marker for FSGS.

HPT (haptoglobin) is reported here as the underrepresented biomarker for FSGS progression with the greatest fold change (2.26). An association between the haptoglobin genotypes and renal function decline in individuals with long-standing type 1 diabetes was previously reported by Costacou et al. (13). The exact role of haptoglobin in progression of FSGS is not well defined and a wide targeted genomic and proteomic experimental design is required for this purpose. In the current study, some of the presented biomarkers have reported before as already known proteins implicated in glomerular disease including: B2MG (14) and AMBP (15), AFAM (6), but most of the other candidates identified in this study are novel. Gene-set enrichment analysis by "DAVID” software (16) resulted in identification of eight significant biological processes of which "acute inflammatory response" ( $\mathrm{P}=$ $\left.5.3 \times 10^{-7}\right)$, "blood coagulation" $\left(\mathrm{P}=2.7 \times 10^{-4}\right)$ and "regulation of homeostatic process" $\left(\mathrm{P}=5.3 \times 10^{-3}\right)$ are the more specific processes relevant to disease progression. Two of the proteins which were in the panel list (composed of 50 proteins) and were enriched in all eight significant processes were A1AG1 (orosomucoid 1) and THRB (prothrombin). We suggest these two proteins are s important proteins implicated in the pathogenesis of FSGS. Pathway analysis against KEGG database using "DAVID" software resulted in two single significant pathways which were also shown to be enriched in the previous study from our group (7) which are the complement and coagulation cascades $\left(\mathrm{P}=8.2 \times 10^{-5}\right)$. It may suggest that impair 
Kalantari S et al.

\begin{tabular}{|c|c|c|c|c|c|c|}
\hline Protein ID & Protein Name & $\begin{array}{l}\text { Biological } \\
\text { Process }\end{array}$ & $\begin{array}{l}\text { Cellular Com- } \\
\text { ponent }\end{array}$ & $\begin{array}{l}\text { Molecular } \\
\text { Function }\end{array}$ & $\begin{array}{l}\text { Fold Change } \\
\text { (Low GFR/high } \\
\text { GFR) }\end{array}$ & $\begin{array}{l}\text { Up/Down } \\
\text { Regulation }\end{array}$ \\
\hline RNAS2 & Ribonuclease 2 & $\begin{array}{l}\text { RNA catabolic } \\
\text { process }\end{array}$ & $\begin{array}{l}\text { Extracellular } \\
\text { region/lysosome }\end{array}$ & $\begin{array}{l}\text { Ribonuclease } \\
\text { activity }\end{array}$ & 7.32 & $\uparrow$ \\
\hline CD59 & $\begin{array}{l}\text { CD59 glycopro- } \\
\text { tein }\end{array}$ & $\begin{array}{l}\text { Negative } \\
\text { regulation of } \\
\text { activation of } \\
\text { membrane at- } \\
\text { tack complex }\end{array}$ & $\begin{array}{l}\text { Anchored to } \\
\text { external side of } \\
\text { plasma mem- } \\
\text { brane/extra } \\
\text { cellular space }\end{array}$ & $\begin{array}{l}\text { Potent in- } \\
\text { hibitor of the } \\
\text { complement } \\
\text { membrane } \\
\text { attack complex } \\
\text { (MAC) action }\end{array}$ & 7.21 & $\uparrow$ \\
\hline PTGDS & $\begin{array}{l}\text { Prostaglandin- } \\
\text { H2 D-isomerase }\end{array}$ & $\begin{array}{l}\text { Prostaglandin } \\
\text { biosynthesis/ } \\
\text { Lipid biosyn- } \\
\text { thesis }\end{array}$ & $\begin{array}{l}\text { Extracellular } \\
\text { space/Golgi ap- } \\
\text { paratus/rough } \\
\text { endoplasmic } \\
\text { reticulum }\end{array}$ & $\begin{array}{l}\text { Fatty acid bind- } \\
\text { ing/prostaglan- } \\
\text { din-D synthase } \\
\text { activity }\end{array}$ & 5.81 & $\uparrow$ \\
\hline B2MG & $\begin{array}{l}\text { Beta-2-micro- } \\
\text { globulin }\end{array}$ & $\begin{array}{l}\text { Regulation } \\
\text { of immune } \\
\text { response }\end{array}$ & $\begin{array}{l}\text { Extracellular } \\
\text { space/MHC } \\
\text { class I protein } \\
\text { complex }\end{array}$ & $\begin{array}{l}\text { Involved in } \\
\text { the presenta- } \\
\text { tion of peptide } \\
\text { antigens to } \\
\text { the immune } \\
\text { system }\end{array}$ & 4.98 & $\uparrow$ \\
\hline АМВР & $\begin{array}{l}\text { Alpha-1-micro- } \\
\text { golbulin }\end{array}$ & $\begin{array}{l}\text { Negative regula- } \\
\text { tion of immune } \\
\text { response }\end{array}$ & $\begin{array}{l}\text { Extracellular } \\
\text { space/plasma } \\
\text { membrane }\end{array}$ & $\begin{array}{l}\text { Serine-type } \\
\text { endopeptidase } \\
\text { inhibitor activ- } \\
\text { ity }\end{array}$ & 4.39 & $\uparrow$ \\
\hline SULF2 & $\begin{array}{l}\text { Extracellular } \\
\text { sulfatase Sulf-2 }\end{array}$ & $\begin{array}{l}\text { Glomerular } \\
\text { basement mem- } \\
\text { brane develop- } \\
\text { ment }\end{array}$ & $\begin{array}{l}\text { Extracellular } \\
\text { space/plasma } \\
\text { membrane }\end{array}$ & $\begin{array}{l}\mathrm{N} \text {-acetylglucos- } \\
\text { amine-6-sulfa- } \\
\text { tase activity/ } \\
\text { calcium ion } \\
\text { binding }\end{array}$ & 4.33 & $\uparrow$ \\
\hline CBG & $\begin{array}{l}\text { Corticosteroid- } \\
\text { binding } \\
\text { globulin }\end{array}$ & $\begin{array}{l}\text { Glucocorticoid } \\
\text { metabolic pro- } \\
\text { cess/regulation } \\
\text { of proteolysis }\end{array}$ & $\begin{array}{l}\text { Extracellular } \\
\text { space }\end{array}$ & $\begin{array}{l}\text { Serine-type } \\
\text { endopepti- } \\
\text { dase inhibitor } \\
\text { activity/steroid } \\
\text { binding }\end{array}$ & 1.61 & $\downarrow$ \\
\hline AFAM & Afamin & $\begin{array}{l}\text { Vitamin trans- } \\
\text { port }\end{array}$ & $\begin{array}{l}\text { Extracellular } \\
\text { space }\end{array}$ & $\begin{array}{l}\text { Vitamin E bind- } \\
\text { ing }\end{array}$ & 1.64 & $\downarrow$ \\
\hline MXRA8 & $\begin{array}{l}\text { Matrix-remod- } \\
\text { eling-associated } \\
\text { protein } 8\end{array}$ & Fibrosis process & Membrane & $\begin{array}{l}\text { May play a role } \\
\text { in the matura- } \\
\text { tion and } \\
\text { maintenance } \\
\text { of blood-brain } \\
\text { barrier }\end{array}$ & 1.71 & $\downarrow$ \\
\hline CO6A1 & $\begin{array}{l}\text { Collagen alpha- } \\
1(\mathrm{VI}) \text { chain }\end{array}$ & $\begin{array}{l}\text { Cell adhesion/ } \\
\text { extracellular } \\
\text { matrix disas- } \\
\text { sembly }\end{array}$ & $\begin{array}{l}\text { Endoplasmic re- } \\
\text { ticulum lumen/ } \\
\text { sarcolemma }\end{array}$ & $\begin{array}{l}\text { Platelet-derived } \\
\text { growth factor } \\
\text { binding }\end{array}$ & 1.74 & $\downarrow$ \\
\hline ACTG & $\begin{array}{l}\text { Actin, cytoplas- } \\
\text { mic } 2\end{array}$ & $\begin{array}{l}\text { Innate immune } \\
\text { response/adhe- } \\
\text { rens junction } \\
\text { organization }\end{array}$ & $\begin{array}{l}\text { Cytoskeleton/ } \\
\text { extracellular } \\
\text { vesicular exo- } \\
\text { some }\end{array}$ & $\begin{array}{l}\text { ATP binding/ } \\
\text { structural } \\
\text { constituent of } \\
\text { cytoskeleton }\end{array}$ & 1.76 & $\downarrow$ \\
\hline HPT & Haptoglobin & $\begin{array}{l}\text { acute-phase } \\
\text { response/posi- } \\
\text { tive regulation } \\
\text { of cell death/re- } \\
\text { sponse to hydro- } \\
\text { gen peroxide }\end{array}$ & $\begin{array}{l}\text { extracellular } \\
\text { space }\end{array}$ & $\begin{array}{l}\text { antioxidant ac- } \\
\text { tivity/catalytic } \\
\text { activity }\end{array}$ & 2.26 & $\downarrow$ \\
\hline
\end{tabular}


ment of complement pathway regardless of the criterion for judgment prognosis determination (either GFR or responsiveness to steroids) plays an important role in the progression and pathogenesis of FSGS. Impairment of this pathway in FSGS progression was consistent with our previous findings in which prognosis was determined based on the response to therapy.

In conclusion, a panel of urinary prognostic biomarkers was reported for FSGS. The most significant over- and underrepresented proteins in patients with worse prognosis in comparison with patients with a better prognosis were RNAS2 and HPT, respectively. These candidates were obtained from a predictive model which clustered patients based on GFR. In conclusion, involvement of proteins responsible for acute inflammatory response and also involvement of complement and coagulation pathways in disease progression were confirmed in our study using bioinformatics methods.

\section{Acknowledgements}

The authors thank the staff of Mass spectrometry lab of Medical Biochemistry and Biophysics department of Karolinska Institute and Urology and Nephrology Research Center and Proteomics Research Center, Shahid Beheshti University of Medical Sciences, Tehran, Iran, for their assistance.

\section{Authors' Contribution}

Shiva Kalantari (performed experiments, wrote the manuscript and analysed the data), Dorothea Rutishauser (performed experiments), Shiva Samavat (collected samples and performed biopsies and wrote the manuscript), Mohsen Nafar (conceived and designed the experiments and performed biopsies), Mostafa Rezaei-Tavirani (Collected samples, wrote the manuscript), Roman Zubarev (Analysed data, wrote the manuscript, contributed reagents/materials/analysis tools).

\section{Financial Disclosure}

There is no conflict of interest.

\section{Funding/Support}

Fouding for this study was provided by the Knut and Alice Wallenberg Foundation, VINNOVA Foundation, Alzheimersfonden as well as the Swedish Research council (Roman A. Zubarev, Dorothea Rutishuser). Urology and Nephrology Research Center of Shahid Beheshti Universi- ty of Medical Sciences (Mohsen Nafar, Shiva Samavat) and faculty of Paramedical Sciences at Shahid Beheshti University of Medical Sciences (Shiva Kalantari, MostafaRezaei-Tavirani) supported this study by sample collection, preparation of biopsies and transporting the samples. The health ministry of Iran supported this study by providing funding for the travel expenses related to the study.

\section{References}

1. D'Agati V. The many masks of focal segmental glomerulosclerosis. Kidney Int. 1994;46(4):1223-41.

2. Fogo AB. Animal models of FSGS: lessons for pathogenesis and treatment. Semin Nephrol. 2003;23(2):161-71.

3. Benchimol C. Focal segmental glomerulosclerosis: pathogenesis and treatment. Curr Opin Pediatr. 2003;15(2):171-80.

4. Schnaper HW. Idiopathic focal segmental glomerulosclerosis. Semin Nephrol. 2003;23(2):183-93.

5. Chitalia VC, Wells JE, Robson RA, Searle M, Lynn KL. Predicting renal survival in primary focal glomerulosclerosis from the time of presentation. Kidney Int. 1999;56(6):2236-42.

6. Kalantari S, Rutishauser D, Samavat S, Nafar M, Mahmudieh L, Rezaei-Tavirani M, et al. Urinary prognostic biomarkers and classification of IgA nephropathy by high resolution mass spectrometry coupled with liquid chromatography. PLoS One. 2013;8(12): e80830.

7. Kalantari S., Nafar M, Rutishuser D. Predictive Urinary Biomarkers for Steroid-resistant and Steroid-sensitive Focal Segmental Glomerulosclerosis Using High Resolution Mass Spectrometry and Multivariate Statistical Analysis. PLOS ONE. 2013;[Epub ahead of print]

8. Trygg J, Wold S. Orthogonal projections to latent structures (OPLS). J Chemometric. 2002;16(3):119-28.

9. Hanamura K, Tojo A, Kinugasa S, Asaba K, Fujita T. The resistive index is a marker of renal function, pathology, prognosis, and responsiveness to steroid therapy in chronic kidney disease patients. Int J Nephrol. 2012;2012:139565.

10. Levey AS, de Jong PE, Coresh J, El Nahas M, Astor BC, Matsushita $\mathrm{K}$, et al. The definition, classification, and prognosis of chronic kidney disease: a KDIGO Controversies Conference report. Kidney Int. 2011;80(1):17-28.

11. Humphrey RL, Karpetsky TP, Neuwelt EA, Levy CC. Levels of serum ribonuclease as an indicator of renal insufficiency in patients with leukemia. Cancer Res. 1977;37(7 Pt 1):2015-22.

12. Bellei E, Cuoghi A, Monari E, Bergamini S, Fantoni LI, Zappaterra $\mathrm{M}$, et al. Proteomic analysis of urine in medication-overuse headache patients: possible relation with renal damages. J Headache Pain. 2012;13(1):45-52.

13. Costacou T, Ferrell RE, Ellis D, Orchard TJ. Haptoglobin genotype and renal function decline in type 1 diabetes. Diabetes. 2009;58(12):2904-9.

14. Flynn FV, Lapsley M, Sansom PA, Cohen SL. Urinary excretion of beta 2-glycoprotein-1 (apolipoprotein $\mathrm{H}$ ) and other markers of tubular malfunction in "non-tubular" renal disease. J Clin Pathol. 1992;45(7):561-7.

15. Varghese SA, Powell TB, Budisavljevic MN, Oates JC, Raymond JR, Almeida JS, et al. Urine biomarkers predict the cause of glomerular disease. J Am Soc Nephrol. 2007;18(3):913-22.

16. Dennis GJ, Sherman BT, Hosack DA, Yang J, Gao W, Lane HC, et al. DAVID: Database for Annotation, Visualization, and Integrated Discovery. Genome Biol. 2003;4(5):P3. 